\title{
Effect of using active learning on the performance of some Skill Factors in Ping Pong
} Dr/ Haytham Gamal El Sayed Ahmed Elgamsy

The Research Problem and Importance:-

Learning is a complex dynamic process involving different types of activity and experience, Scientists have tried throughout the ages to explain the process of learning and how it occurs, Where there are many branches of the educational process, including motor learning, which distinguishes the life of the organism from birth to death It is a process aimed at acquiring motor skills and physical abilities and improving the process of choosing appropriate behavior in different situations.

Teaching methods are one of the cornerstones of the educational process, It is a tool for connecting teacher and learner Through it the teacher transfers information, knowledge and ideas to the pupils and acquires them a lot of skills and concepts In order to improve their performance and achieve the desired objectives of the teaching process.

So, the methods and methods of teaching have recently received a lot of study and research to find the most suitable for both the teacher and the learner and the nature of the material that is offered, The teaching methods used in teaching physical education courses are the main pillar to achieve the objectives of teaching and training those courses.

Hence the trend towards active learning as one of the important methods and mechanisms in teaching in pursuit of the teaching and learning process, And achieving total quality in education, The transfer of learning from traditional methods based on memorization and conservation and application to more positive methods and strategies based on the effectiveness of the learner and his involvement in the process of education to develop aspects of personality and abilities and intelligence.

Ping Pong curriculum is one of the main curricula influenced by the rapid development of the educational process, It became necessary to develop the teaching of the content of this curriculum to suit the nature of the 
performance of his new skills and inspired by the innovative creative thinking Which goes handing with the continuous development of Ping Pong, And you need Practical Curriculum Aspects of Physical Education Lesson Teach motor skills associated with mathematical skills to reach the stage of stabilization and mastery and the actual practice of the skill, Ping Pong course in physical education lectures is one of the practical courses that contain many important skills, And high difficulty for both teacher and learner

Also considered The undergraduate student represents the main pillar in learning and developing the game and therefore the process of preparing these students The sample is based on the development of the level of performance through their education and preparation in accordance with the characteristics of the age appropriate for them, and by observing the researcher while teaching the course of Racquet Sports (Ping Pong) For students of the first year at the Faculty of Physical Education Boys Zagazig University, Note that there is a variation in students' performance when learning some of the motor skills of Ping Pong, The importance of the study is illustrated by the importance of the subject that will be addressed, which is to address the shortcomings in learning the basic methodological skills in Ping Pong For the first year college students, Active learning has several advantages that make it better than traditional education because it encourages student cooperation and activity within the lecture and eliminates monotony and boredom, Students in active learning work to achieve the work that is required of them, and creates an atmosphere of affection and intimacy among students who have not used to it before, because the current teaching methods do not encourage interaction and cooperation,

The importance of active learning in Ping Pong is due to the fact that its main focus is the student and the faculty member and the decision to get the information, and, Active learning inspires confidence in the same student, and develops thinking and innovation in the implementation of skills performance, and The learning process remains kept longer and longer, as it reaches him and his colleagues through their efforts during 
performance, and The study also builds an active learning program for Ping Pong skills because of its effective role in raising the level of skill performance, and Using active learning strategies, so program also helps develop positive interaction between learners and teachers.

This research aims at knowing the influence of Effect of a suggested learning program using active learning method on learning some basic Ping Pong skills For students of the first year at the Faculty of Physical Education Boys Zagazig University.

* The Research Executions: The Sample:

The researcher has used the experimental method by using the experimental design for two groups; the first experimental and the other

\section{Table (1)
The Coren}

The Coherence of the total Research Sample in all Research Variables

\begin{tabular}{|c|c|c|c|c|c|c|}
\hline & Variables & 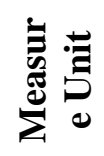 & 总 & 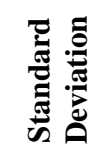 & $\sum_{\Sigma}^{\mathbb{E}}$ & 芯 \\
\hline \multirow{3}{*}{ 焉 } & Age & Year & 17.11 & .671 & 17.10 & 0.078 \\
\hline & Height & C.M & 167.62 & 3.350 & 164.00 & 0.438 \\
\hline & Weight & K.G & 65.92 & 3.461 & 63.00 & $0.033-$ \\
\hline \multirow{3}{*}{$\frac{5}{5}$} & Response speed & Sec. & 8.12 & 3.242 & 8.00 & 0.129 \\
\hline & Speed & Sec & 4.43 & 2.821 & 6.20 & $0.032-$ \\
\hline & $\begin{array}{c}\text { Power characteristic } \\
\text { of speed }\end{array}$ & M. & 4.10 & 1.257 & 5.00 & -0.268 \\
\hline
\end{tabular}

controlled, following the pre and post measurement a8 it is suitable for this study. The research society consists of (350) Students, The first year of the Faculty of Physical Education Boys Zagazig University for the academic year 2018/2019. Then the researcher chose the research sample by the hazard way, they are (40) Students by percentage $(11.42 \%)$ from the research society. He got (12) Students for doing the experimental study, so the main research sample is (28) Students. They are divided as follows:

The experimental group (14) Students who have the visual training, and the controlled group (14) Students. * The Statistic Description of the total Research Sample (Coherence): 
Follow Table (1)

The Coherence of the total Research Sample in all Research Variables

\begin{tabular}{|c|c|c|c|c|c|c|}
\hline \multicolumn{7}{|c|}{$\mathrm{N}=\mathbf{4 0}$} \\
\hline \multicolumn{2}{|r|}{ Variables } & 胥 & 离 & 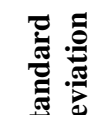 & ‡్ & 氮 \\
\hline \multirow{4}{*}{ 焉 $\overline{\mathrm{g}}$} & Grace & $\overline{~ C . M ~}$ & 30.8 & 1.571 & 27.00 & 0.109 \\
\hline & Flexibility & C.M & 2.22 & 1.242 & 3.00 & 0.501 \\
\hline & Consistency & Sec. & 27.70 & 5.463 & 26.00 & 0.301 \\
\hline & Accuracy & Sec. & 63.21 & 7.634 & 62.00 & 0.084 \\
\hline \multirow{5}{*}{ 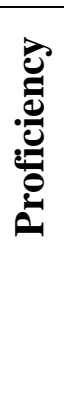 } & $\begin{array}{c}\text { Serving by the front } \\
\text { Racket face }\end{array}$ & Point & 1.20 & 0.745 & 0.80 & 0.403 \\
\hline & $\begin{array}{c}\text { Serving by the back } \\
\text { Racket Face }\end{array}$ & Point & 1.45 & 0.934 & 1.75 & 0.225 \\
\hline & $\begin{array}{l}\text { Straight Stroke by } \\
\text { the front Racket Face }\end{array}$ & Point & 2.10 & 0.783 & 2.20 & 0.192 \\
\hline & $\begin{array}{c}\text { Straight Stroke by } \\
\text { the back Racket Face }\end{array}$ & Point & 0.71 & 0.651 & 1.00 & 0.461 \\
\hline & $\begin{array}{l}\text { Pushing by the front } \\
\text { Racket face }\end{array}$ & Point & 1.32 & 0.312 & 1.38 & -0.846 \\
\hline
\end{tabular}

From Table (1) we notice that all standard deviations values in the growth variables and some physical and proficiency variables in ping pong, they are between $(-0.846,0.461)$, so they are between $( \pm 3)$ that refer to the homogeneity of the members of research sample in these variables.

Methods and tools of Collecting Data: First: The Sets and tools:

- Rastametre set for measuring height and weight.

- Measuring Height Tape (by centimeter) - wooden cones collars.
- 0.1 second - ping pong rackets - tennis tables.

They are compared by other sets to standard them for the validity of the measuring tools.

Second: The physical Tests (Appendix 3):

The researcher has determined the physical variables and the tests which measure them, through the specialized scientific resources and the precious studies, by collecting all the physical characteristics related to ping pong under research, also the physical tests related to them, and the 
specialist experts show them to determine the most important physical characteristics 8uitable for this research, also the physical tests which measure them (Appendix 2). They are revised by ten experts in Methodology and ping pong (Appendix 2). The researcher chose $70 \%$ or more for the most physical variables then he accepted the following tests:

Motor speed of arm. (To measure the kinetic speed), and Speed of response. (To measure the ball driven from the machine).and push a medical ball weighing $1.5 \mathrm{~kg}$. (To measure the characteristic force at speed). and running Zigzag way Bauer $3 \times 4.5 \mathrm{~m}$. (To measure agility), and bend the trunk forward from standing. (To measure flexibility), and Numbered circles fast. (To measure compatibility), and he accuracy of passing the tennis ball of movement. (To measure accuracy)

\section{Third: The Proficiency Tests} (Appendix 5)

Through looking in many specialized scientific resources that have been done in ping pong field, and by assistance of some test Battery Units for the basic skills in ping pong, as the study of Mohamed Saad El Deen El
Sayed (2002), Magdy Ahmed Shawky (2002) Fathy Ahmed El Saqaf (2010).

The researcher has asked the opinion of the experts (Appendix 2) for counting the most important tests that measure these skills. He chose the percentage $70 \%$ or more for the most important proficiency variables. He accepted the following proficiency tests:

- Serving by the front racket face, and serving by the back racket face.

- Pushing by the front racket face

- Straight strorke by the front racket face, and the straight stroke by the back racket face.

\section{The Experimental Study:}

The researcher has done an experimental study on (12) Students from the research society; out the main research sample, in the period from $15 / 9$ to $18 / 9 / 2018$ to emphasize the validity of the used place, and tools and sets for performing the measurements and tests, and know the troubles that may face the researcher during the measurements and tests, and train the assistants on doing the measurements and test, and organize the sample members for doing the measurements and tests in less time and effort, and emphasize the validity of 
the register from, and know the scientific factors (reliability Steadiness) for tests under research.

The Suggested Educational Program (Appendix 6): The researcher took the opinion of the experts (Appendix 1) around determine the most important Physical exercises that influence some proficiency variables in ping pong under research, then he prepared the suggested educational program.

Contents of the Educational Program: The suggest educational program contains Physical exercises that help in improving the performance level of some pingpong skills under research for the first grade Students by what agree with the variables nature under the research.

Time of the Educational program: The program contains eight weeks for 16 Units two units a week, each unit 45 minutes.

The researcher put these exercises in the figure of a program that suits the research objectives. He took away the exercises that the experts do not agree with. The final agreeable exercises are (40) (Appendix 7).

The pre - measurements: After being used the scientific factors (steadiness reliability) of the proficiency tests in ping pong under research through the experimental study by doing the pre-measurements on the experimental and controlled research sample during 29, 30/9/2018.

\section{Measuring the proficiency performance level:}

The researcher has measured the proficiency performance level in ping pong under research by a committee of three refrees (Appendix 7).

\section{The Main Study:}

The researcher has applied the suggested educational program by using the visual training on the experimental group while applying the traditional method (oral explanation - giving the practical model) on the controlled group in the period from $1 / 10 / 2018$ to $27 / 11 / 2018$ for eight weeks. They contain (16) educational unit, two units a week. The researcher has followed the following steps:

\section{The Post Measurements:}

$\mathrm{He}$ hasdone the post measurements after the eighth week on the two groups; the experimental and the controlled on 29, 30/11/2018. they contain the same premeasurements and by the same conditions.

\section{Assiut Journal For Sport Science Arts}


The Statistics Treatment:

He has used the suitable statistics treatment for the mature of the research by using
(SPSS) program for performing the mathematical and statistic research Operations.

Discussing the Results:

\section{Table (2)}

The Statistic Differences Denotations Between The Averages of Pre and Post Measurements for the Experimental Group in Some ping pong Skills Under Research $\mathrm{N}=14$

\begin{tabular}{|c|c|c|c|c|c|c|c|}
\hline & \multirow[t]{2}{*}{ Variables } & \multirow{2}{*}{$\begin{array}{c}\text { Measure } \\
\text { Unit }\end{array}$} & \multicolumn{2}{|c|}{$\begin{array}{c}\text { Pre- } \\
\text { Measurement }\end{array}$} & \multicolumn{2}{|c|}{$\begin{array}{c}\text { Post } \\
\text { measurement }\end{array}$} & \multirow{2}{*}{$\begin{array}{c}\mathbf{T} \\
\text { Value }\end{array}$} \\
\hline & & & $S_{1}$ & $\pm M^{1}$ & $\mathbf{S}_{2}$ & $\pm \mathbf{M}^{2}$ & \\
\hline \multirow{5}{*}{ 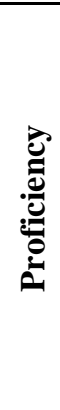 } & $\begin{array}{l}\text { Serving by the front } \\
\text { racket face }\end{array}$ & Point & 2.25 & 1.252 & 5.61 & 1.829 & $9.575^{*}$ \\
\hline & $\begin{array}{l}\text { Serving by the back } \\
\text { racket face }\end{array}$ & Point & 1.60 & 0.635 & 4.42 & 0.826 & $10.127^{*}$ \\
\hline & $\begin{array}{l}\text { Straight Stroke by } \\
\text { front racket face }\end{array}$ & Point & 2.25 & 0.814 & 5.75 & 1.234 & $8.859^{*}$ \\
\hline & $\begin{array}{l}\text { Straight Stroke by } \\
\text { back racket face }\end{array}$ & Point & 0.70 & 0.321 & 3.50 & 0.602 & $15.356^{*}$ \\
\hline & $\begin{array}{l}\text { Pushing by the front } \\
\text { racket face }\end{array}$ & Point & 1.70 & 0.335 & 4.25 & 0.967 & $9.323^{*}$ \\
\hline
\end{tabular}

"T" tabled value in the level $0.05=2.160$

from Table (5) shows experimental group in all table that there are statistically tennis skills under significant differences at the consideration and in favor of 0.05 level between the pre and the telemetry. post measurements of the

Table (3)

The statistics Difference Denotations between the Averages of pre and post Measurements for the controlled Group in some proficiency variables in ping pong under Research $\mathrm{N}=14$

\begin{tabular}{|c|c|c|c|c|c|c|c|}
\hline & \multirow[t]{2}{*}{ Variables } & \multirow{2}{*}{$\begin{array}{l}\text { Measure } \\
\text { Unit }\end{array}$} & \multicolumn{2}{|c|}{$\begin{array}{c}\text { Pre- } \\
\text { Measurement }\end{array}$} & \multicolumn{2}{|c|}{$\begin{array}{c}\text { Post } \\
\text { measurement }\end{array}$} & \multirow[t]{2}{*}{$\begin{array}{c}\mathbf{T} \\
\text { Value }\end{array}$} \\
\hline & & & $S_{1}$ & $\pm M^{1}$ & $\mathbf{S}_{2}$ & $\pm \mathbf{M}^{2}$ & \\
\hline \multirow{2}{*}{ 窇 } & $\begin{array}{l}\text { Serving by the front } \\
\text { racket face }\end{array}$ & Point & 2.30 & 1.270 & 3.75 & 1.613 & $2.643^{*}$ \\
\hline & $\begin{array}{l}\text { Serving by the back } \\
\text { racket face }\end{array}$ & Point & 1.65 & 0.645 & 2.30 & 0.718 & $2.520^{*}$ \\
\hline
\end{tabular}


Follow Table (3)

The statistics Difference Denotations between the Averages of pre and post Measurements for the controlled Group in some proficiency variables in ping pong under Research $\mathrm{N}=14$

\begin{tabular}{|c|c|c|c|c|c|c|}
\hline \multirow[t]{2}{*}{ Variables } & \multirow{2}{*}{$\begin{array}{c}\text { Measure } \\
\text { Unit }\end{array}$} & \multicolumn{2}{|c|}{$\begin{array}{c}\text { Pre- } \\
\text { Measurement }\end{array}$} & \multicolumn{2}{|c|}{$\begin{array}{c}\text { Post } \\
\text { measurement }\end{array}$} & \multirow{2}{*}{$\begin{array}{c}T \\
\text { Value }\end{array}$} \\
\hline & & $\mathbf{S}_{1}$ & $\pm M^{1}$ & $\mathbf{S}_{\mathbf{2}}$ & $\pm M^{2}$ & \\
\hline $\begin{array}{l}\text { Straight Stroke by } \\
\text { front racket face }\end{array}$ & Point & 2.15 & 0.823 & 3.25 & 1.217 & $2.801^{*}$ \\
\hline $\begin{array}{c}\text { Straight Stroke by } \\
\text { back racket face }\end{array}$ & Point & 0.75 & 0.335 & 2.00 & 0.892 & $4.909^{*}$ \\
\hline $\begin{array}{l}\text { Pushing by the front } \\
\text { racket face }\end{array}$ & Point & 1.60 & 0.324 & 2.15 & 0.476 & $3.574^{*}$ \\
\hline \multicolumn{7}{|c|}{ "T" tabled value in the level $0.05=2.160$} \\
\hline \multicolumn{7}{|c|}{ From table (3) The of } \\
\hline \multicolumn{2}{|c|}{$\begin{array}{l}\text { presence of statistically } \\
\text { significant differences between } \\
\text { the pre and post measurements }\end{array}$} & \multicolumn{5}{|c|}{$\begin{array}{l}\text { skills under } \\
\text { on and in favor of }\end{array}$} \\
\hline
\end{tabular}

Table (4)

The Denotation of the Statistic Differences between the Averages of the two post measurements for the two group; the experimental and the controlled, in some ping pong skills under Research $\mathrm{N}_{1}=\mathrm{N}_{2}=14$

\begin{tabular}{|c|c|c|c|c|c|c|c|}
\hline & \multirow[t]{2}{*}{ Variables } & \multirow{2}{*}{$\begin{array}{c}\text { Measure } \\
\text { Unit }\end{array}$} & \multicolumn{2}{|c|}{$\begin{array}{c}\text { Pre- } \\
\text { Measurement } \\
\end{array}$} & \multicolumn{2}{|c|}{$\begin{array}{c}\text { Post } \\
\text { measurement } \\
\end{array}$} & \multirow{2}{*}{$\begin{array}{c}T \\
\text { Value }\end{array}$} \\
\hline & & & $S_{1}$ & $\pm M^{1}$ & $\mathbf{S}_{2}$ & $\pm \mathrm{M}^{2}$ & \\
\hline \multirow{5}{*}{ 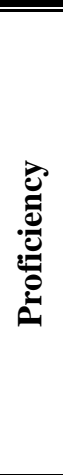 } & $\begin{array}{l}\text { Serving by the front } \\
\text { racket face }\end{array}$ & Point & 4.50 & 0.624 & 3.25 & 0.462 & 8.670 \\
\hline & $\begin{array}{l}\text { Serving by the back } \\
\text { racket face }\end{array}$ & Point & 3.25 & 0.341 & 2.30 & 0.367 & 10.212 \\
\hline & $\begin{array}{l}\text { Straight Stroke by } \\
\text { front racket face }\end{array}$ & Point & 2.34 & 0.489 & 1.30 & 0.538 & 7.703 \\
\hline & $\begin{array}{l}\text { Straight Stroke by } \\
\text { back racket face }\end{array}$ & Point & 4.20 & 0.657 & 2.64 & 0.765 & 8.331 \\
\hline & $\begin{array}{l}\text { Pushing by the front } \\
\text { racket face }\end{array}$ & Point & 3.75 & 0.563 & 3.00 & 0.638 & 4.747 \\
\hline
\end{tabular}

"T" tabled value in the level $0.05=2.052$

Assiut Journal For Sport Science Arts 
From table (4) The presence of statistically significant differences between the experimental and control

\section{Table (5)}

groups in the telemetry of the tests of table tennis skills under consideration and in favor of the experimental group

The Percentages of the post Measurement Improvement than the premeasurement for the experimental and controlled groups in some ping pong skills under Research

\begin{tabular}{|c|c|c|c|c|c|c|c|}
\hline \multirow[b]{2}{*}{ Variables } & \multicolumn{3}{|c|}{ Experimental Group } & \multicolumn{3}{|c|}{ Controlled Group } & \multirow{2}{*}{$\begin{array}{c}\text { Change } \\
\text { Rate }\end{array}$} \\
\hline & Pre & Post & $\begin{array}{c}\text { Improve } \\
\text { Per. \% }\end{array}$ & Pre & Post & $\begin{array}{l}\text { Improve } \\
\text { Per. \% }\end{array}$ & \\
\hline $\begin{array}{l}\text { Serving by the front } \\
\text { racket face }\end{array}$ & 2.25 & 5.61 & 149.33 & 2.30 & 3.75 & 63.04 & 86.29 \\
\hline $\begin{array}{l}\text { Serving by the back } \\
\text { racket face }\end{array}$ & 1.60 & 4.42 & 176.25 & 1.65 & 2.30 & 39.39 & 136.86 \\
\hline $\begin{array}{l}\text { Straight Stroke by } \\
\text { front racket face }\end{array}$ & 2.25 & 5.75 & 155.56 & 2.15 & 3.25 & 51.16 & 104.4 \\
\hline $\begin{array}{c}\text { Straight Stroke by } \\
\text { back racket face }\end{array}$ & 0.70 & 3.50 & 400.0 & 0.75 & 2.00 & 166.6 & 233.3 \\
\hline $\begin{array}{l}\text { Pushing by the front } \\
\text { racket face }\end{array}$ & 1.70 & 4.25 & 150.0 & 1.60 & 2.15 & 34.38 & 115.62 \\
\hline
\end{tabular}

Table (5) The presence of progression rates for telemetry from the tribal groups of the experimental and control groups in all the basic skills in table tennis under consideration where the experimental group in these ratios outperformed the control group.

\section{Discussion of the results:}

The results of table (4) that there are statistically significant differences at the level of 0.05 between the pre and post measurements of the experimental group in all table tennis skills under consideration and in favor of telemetry, the researcher attributed these differences to the use of active learning method, which depends on the development of table tennis skills through A set of teaching strategies such as brainstorming, peer exchange, discussion, problem solving, thinking out loud, used in the learning process of the methodological skills in table tennis to be learned has resulted in significant statistical differences of significance greater than the level of moral 0.05 , which positively affected 
In the results of measurements of skill tests, as well as the model carried out by the teacher and his commitment to provide a set of gradual educational steps for each skill taking into account the order of easy to difficult as it works to spread the spirit of competition, excitement and suspense, and the division of the students themselves into even groups that the student chooses his colleague freely taking into account Practice and repetition of the learner and correct mistakes, which provides opportunities for learning which positively affects the efficiency of skill performance.

This indicates that the use of active learning method has a positive effect on learning the table tennis skills the methodology under consideration is due to the good selection of the teacher for standardized exercises to teach and develop the performance of each skill individually, and the teacher to explain and perform a model of the exercise and make all decisions on education in the light of a group Some of the questions to be answered require students to follow a set of procedures is to give (a period of reflection - a period of experimentation - a period of discussion - discover the correct movement and agreed upon) followed by students to perform a set of exercises and follow-up learners during the performance and give feedback to Jawdat Ahmad Saadeh (2006) notes that active learning involves students in activities and exercises very effectively, and through a rich and diverse learning environment that allows them to listen positively or constructively to dialogue, and to have a rich discussion. Conscious thinking, continuous analysis, and deep reflection on all the topics that are raised, between each other with a learner encourages them to take responsibility for the education of themselves under his close supervision, and motivates them to achieve the ambitious goals of the curriculum, which is based on building an integrated personality and creative.

This is consistent with what Breslow (1999), Sharon and Martha (2001), Hall, et al (2002), and Mathews (2006), 
Donald \& Jennifer (2008), that active learning aims to provide an educational environment rich in stimuli, which allows the learner the responsibility to teach himself and participate effectively through research, access and use of the higher mental abilities to access knowledge under the guidance and supervision of the teacher, An atmosphere of intimacy and cooperation between members of the class or group. These results are consistent with those of Amal Raja Saif (2009), Amani Sayed Farghaly (2009) , Salwa Mohamed Azazi (2009), Iman Lotfy Abdel Hakim (2010), Heba Abdullah Ramadan (2010), Salwa Abdul Latif Ahmed (2011) , Hussein Ali Hamad (2012) which indicate the effectiveness of using active learning method in developing and improving the skills applied

So the first hypothesis, which states that "there are statistically significant differences between the pre and post measurements of the experimental group in learning some basic table tennis skills and in favor of telemetry, is validated.

The results of Table (5) that there are statistically significant differences between the pre and post measurements of the control group in all table tennis skills under consideration and for the benefit of telemetry, the researcher is due to the use of the traditional method in teaching table tennis skills, which was applied to the members of the control group, which depends on " Verbal explanation of the skills in question to be learned as well as the "model" by the teacher and his commitment to provide a set of gradual learning steps from easy to difficult and practice and repetition of the learner and correct errors, as this provides opportunities for learning which positively affects the efficiency of skill performance, and Thus, the positive impact that is available in the traditional method, which provides a set of features, including explaining the technical performance and provide a model of the skill required to be taught by the teacher and control of students and the use of different 
formations during the lesson of physical education, which brings with it the spirit of order and discipline on the lesson and try some students to implement orders In addition to the importance of teacher-tostudent feedback, which is correcting errors for students while performing tennis skills. Which contributes positively to the development of the knowledge aspect more effectively.

This is consistent with Lamia Fawzi Mahrous (2000) that the presence of the teacher is important in terms of constructive instructions and explanation of performance and technical steps in a good way and correct errors with the ability of the teacher to communicate information about performance in the correct way to the pupils and the repetition of the teacher and correct errors Provides pupils with suitable learning opportunities, which positively affects performance efficiency So the second hypothesis, which states that "there are statistically significant differences between the preand post-measurements of the control group in learning some basic table tennis skills and in favor of telemetry, is validated."

The results of Table (5) that there are statistically significant differences between the experimental and control groups in the telemetry tests of table tennis skills under consideration and for the benefit of the experimental group. Dimension of the experimental group indicates that working in an active learning mode allows students to be treated individually in a cooperative framework, where the student advances according to his / her own speed, so that individual differences between students can be taken into account during the learning process. The students of the experimental group that follows the active learning method urged the students of the control group who follow the traditional method in the majority of table tennis skills under consideration to differ from the active learning environment from the traditional learning environment, as it is characterized by openness and democracy, it is an intellectual system and a set of practical 
practices leading to Situations in which teaching and learning take place effectively, so that the learning environment extends beyond the lecture of physical education from sources of learning, whether in the library, the Internet, the teacher or others, all of which support independent learning (self), and enhance selfconfidence, With skills, mental abilities and also the possibility of change by students in the selection process, learning may be conducted in an individual way that supports independent learning, or learning in small groups and in various forms such as peer or collaborative learning, and can be divided into homogeneous groups,

This is consistent with the results of the study of Hussein Ali Hamad (2012), Heba Abdullah Ramadan (2010), which indicates the effectiveness of the use of active learning method compared to the traditional method (explanation and model) due to the important role played by the student In the educational process, making it achieves learning faster than traditional methods of education.
So the third hypothesis is validated, which states that "there are statistically significant differences between the two dimensions of the experimental and control groups in learning some basic skills in table tennis and for telemetry."

Results

and Recommendations: First: The Results: The visual training influences the improvement of the ping pong skills performance (serving by the front and the back racket face pushing by the front and the back racket face), and influence of the orders method on the controlled group in ping pong skills performance under research for pupils is very little; compared by the influence of the visual training on the experimental group, and statistic differences between the two post measurements for the experimental and the controlled group in ping pong skills performance under research for the side of the experimental group, so experimental group has higher improvement percentages in all ping pong skills under research than the controlled group. 
Second: Recommendations:-

1- The need to apply the proposed educational program using the active learning method in learning basic skills in table tennis for students of the first year of the Faculty of Physical Education for what proved the results of this study. 2- Work on the integration of many teaching strategies during active learning to make the most of the capabilities and capabilities of students to use in the process of learning motor skills in sports activities in general and ping pong 3- not to neglect the role of the teacher in arousing students' motivations and guidance during the exercise of various educational activities.

pay attention to the visual training as it has an effective influence on developing the ping pong skills performance level under research.

\section{References}

1- Ahmed Hussein Allakani :Teaching Aids and School Curriculum, Arab Gulf Foundation, Cairo, 2006.

2- Asmaa Ismail Ahmed: "The Effect of Using Dalton Method on the Level of Learning Some Basic Skills in Basketball for Female Students in Faculty of Physical Education, Assiut University, Master Thesis, Faculty of Physical Education, Assiut University, 2010.

\section{3-Imam Mukhtar Hamida,} Ahmed Najdi, Salahuddin Arafa: Teaching Skills, Zahra Library, Cairo, 2000.

\section{4- Amani Sayed Farghaly} Selim: The Effect of Active Learning on the Development of Innovative Thinking and Academic Achievement in the First Cycle of Basic Education, Master Thesis, Institute of Educational Studies, Department of Educational Psychology, Cairo 2009.

5- Amal Raja Saif: the effectiveness of a proposed program on active learning in the acquisition and use of students of the Faculty of Specific Education some skills of teaching computer, Master Thesis, Faculty of Education, Minia University, 2009.

6- Amin Anwar El-Kholy, Mahmoud Abdel Fattah Annan: Mathematical Knowledge, Dar Al-Fikr AlArabi, Cairo, 1999.

\section{7- Iman Lutfi Abdel Hakim:} the impact of a proposed program based on active learning in the development of 
some scientific concepts and some mental skills of Riyadh children, Ph.D. Thesis, Faculty of Education, Minia University, 2010.

8- Jawdat Ahmad Saadeh: Active Learning between Theory and Practice, Dar Al Shorouk Publishing, Amman, Jordan, 2006.

9- Hussein Ali Hamad AlSaeed: The Effectiveness of Active Learning in Developing Some Cognitive and Skills Aspects of Athletics Skills for Children in Kuwait, PhD Thesis, Faculty of Physical Education for Boys, Zagazig University, 2012.

10- Said Khalil Al-Shahed: Methods of Teaching Physical Education, Students Library, Cairo, 1995.

\section{1- Salwa Abdel Latif} Ahmed: Effectiveness of using active learning supported electronically on the level of performance of some motor skills and its relation to the innovative thinking of the pupils of the Foundation Stage in the UAE, Master Thesis, Faculty of Physical Education for Girls, Zagazig University, 2011.

12- Salwa Mohammed Azazi: active learning between theory and practice, House of Culture, Amman, Jordan, 2008.

13- Fathi Ahmed Al-Saqqaf (2010): Table Tennis "Skills Stages of Growth - Selection Trainer", Horus International Publishing, Cairo

14- Lamia Fawzi Mahrous: Effect of using some teaching methods on the level of skill performance and motivation of some basic skills in basketball for the students of the Faculty of Physical Education in Tanta, $\mathrm{PhD}$ Thesis, Faculty of Physical Education, Tanta University, 2000.

15- Magdy Ahmed Shawky (2002): Table Tennis

Fundamentals of Theory and Practical Applications, Arab Center for Publishing, Zagazig.

16- Mohamed Saad El-Din (2002): Sports Curriculum Series, Table Tennis Curriculum, Information and Documentation

Center

Publishing Department, Leadership Development Sector, Supreme Council for Youth and Sports, Giza. 17- Mohamed Mahmoud Abdel Dayem, Mohamed Sobhy Hassanein: Modern basketball in scientific and applied bases, "LearningMeasurement- Selection- 
Law", 2nd floor, Dar Al Fikr Al Arabi, Cairo, 1999.

18-

Heba

Abdullah

Ramadan: The Effectiveness of a Program Based on Active Learning Strategies in Teaching Social Studies to Develop Historical Thinking Skills among Preparatory Students, PhD Thesis, Faculty of Education, Helwan University, 2010.

19- Breslow, L.,: New Research Point to the Importance of using Active Learning in the Classroom. Teach Talk Articles in the faculty New Letter VXIII. NI, 1999.

20- Donald, R., Paulson \& Jennifer, L., Fause, T.,: Active Learning for the College Classroom, Available at http//www.calstatela. edu/dept/chem/chem2/actie, 2008.
21- Hall, D., Watiz, I., Bordeur, \& D., Nas, R.,: Adoptional of Active Learning in alectrureBased Engineering Class. ASEE/ IEEE Frontiers in Conference, Boston, 2002. 22- Mathews, L.k.,: Element Of Active Learning, Available at http:// www.2una.edu/ geograghy/ Active /element htm, 2006.

23- Schmidt, R.A.,:

Motor Learning and Performance, Illinois, Human Kinetic Book, 1999.

24- Sharon, D., \& Martha, L.,: Learning and development New York, McGraw, Hill Book Co., 2001. 